\title{
Thioethers in urine during occupational exposure to tetrachloroethylene
}

\author{
AMALIA LAFUENTE AND J MALLOL \\ From the Department of Pharmacology, School of Medicine, University of Barcelona, REUS (Tarragona), \\ Spain
}

With the aim of finding out if tetrachloroethylene (perchloroethylene, PER) can be eliminated as a thioether derivative, we performed a pilot study with six women (aged 30-50) employed in different dry cleaning workshops. Five worked in the cleaning areas and were non-smokers; the sixth worked at a desk and was a heavy smoker (more than 20 cigarettes a day). PER concentrations in these areas at the end of the working day varied from 15 to $50 \mathrm{ppm}$, measured with the aid of Dräger tubes.

Urinary thioethers were determined in urine collected at the end of an eight hour working period and stored at $-20^{\circ} \mathrm{C}$ until required (not longer than 15 days). Urine collected on non-working days was taken at about the same time of day. In the group study we collected urine from the six workers on any of three working days and on one Sunday. In the individual study (case 3) we followed up the thioether excretion for a continuous period of two weeks.

Thioethers were quantified by the method described by Van Doorn et al, ${ }^{1}$ and referred to the creatinine values (samples with creatinine values under $5 \mathrm{mmol} / 1$ were discarded).

The results obtained in the group study (fig 1) show that throughout the week, thioethers gradually increase reaching their maximum value at the end of the period studied. This increase follows an apparent constant rate and individual " $r$ " values vary from 0.95 to $0 \cdot 99$, except obviously for case 2 . Case 3 was subjected to a continuous study throughout two weeks and the results are shown in fig 2 , from which it may be seen that thioether values increase throughout the working period, with clear cut lower thioether values after the three rest days.

Despite this conspicuous increase, all the values remain between the control limits previously obtained by us in non-smokers-non-exposed people (from 2 to $12 \mathrm{mmol} / \mathrm{mol}$ creatinine, not shown here). This may be due to the low exposure to PER or to an insufficient

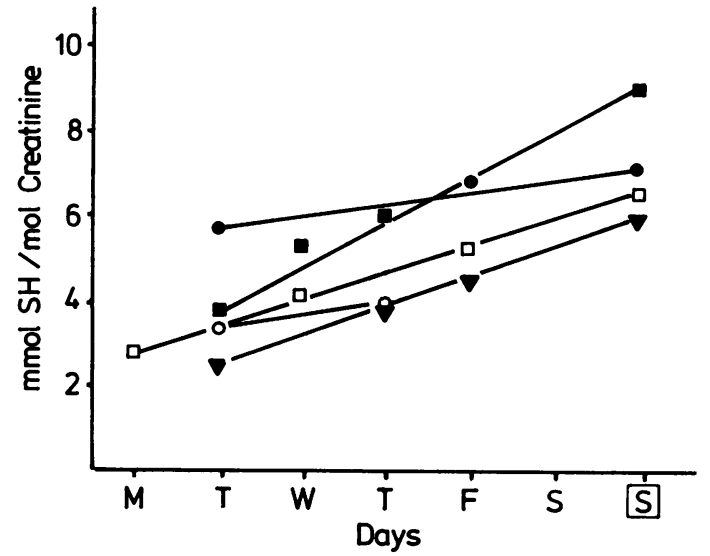

Fig 1 Urinary thioethers in women exposed to PER. S (Sunday) is a non-working day. Case 1, $\bigcirc$ case 2, case 3, $\square$ case 4, $\nabla$ case 5. Data not plotted when mean creatinine values are $<5 \mathrm{mmol} / \mathrm{l}$. For case 6 (desk worker) only one point was available (Wednesday) $=3.6 \mathrm{mmol} \mathrm{SH} /$ mol creatinine.

recovery by the method used here (ethyl acetate extraction). Hence, it is evident that in these conditions monitoring with only one individual determination is not worth while. Direct hydrolytic methods, as described by Vainio et $\mathrm{al}^{,}{ }^{2}$ may be useful only when working with a larger number of subjects, $\rightarrow$ but in our case the ethyl acetate extraction seemed to be more suitable to avoid large individual variations $N$ caused mainly by endogenous cystine.

The exact mechanism underlying our observations 0 -that is whether PER may be coupled directly or via $\mathrm{\omega}$ an electrophilic intermediate-remains to be clarified. In this sense Yllner, from his experiments on mice, suggested that an epoxide was formed from PER, ${ }^{3} \mathbb{\Phi}$ which would be further converted to tri- $\stackrel{?}{+}$ chloroacetylchloride as one of the metabolic path- 꿍 ways of PER. This epoxide, in our opinion, could easily be converted to a thioether. 


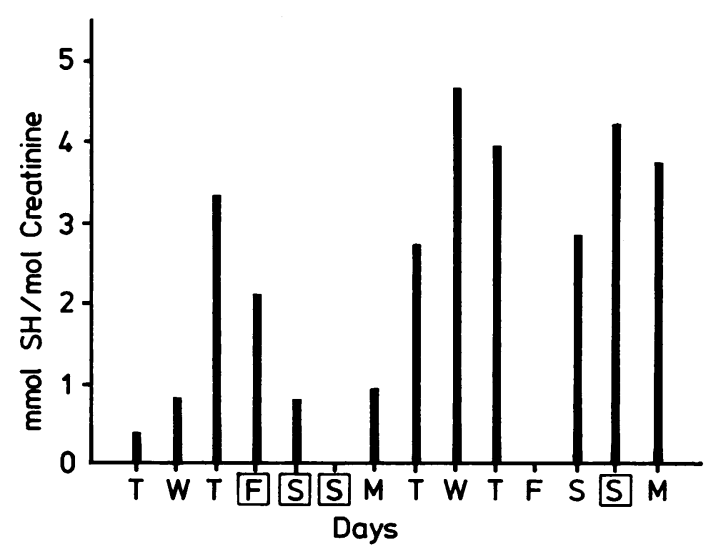

Fig 2 Continuous study in case 3. Squared days refer to non-working days.

Probably, the total amount of thioethers excreted represents a low percentage of the total PER intake of each working day, as PER is mainly eliminated through the lungs. ${ }^{4}$ The relevance of our observations needs further investigation, but the formation of a thioether derivative from PER may represent an interesting detoxification process in acute intoxications or in long term high exposures to PER.
We thank Professor P T Henderson (University of Nijmegen) for his helpful collaboration and for reviewing our results. We are also indebted to Jordi Jara for his skilful technical help and to E Salazar for his contribution in the measurements of PER in working areas. We are also grateful to Professor J Bosch for his contribution in the creatinine determinations.

Amalia Lafuente belongs to the Fellowship Programme "Formación del Personal Investigador" of the Spanish Government in which we are contributing with the work presented here.

This work was supported in part by a grant from the Departament d'Ensenyament - Generalitat de Catalunya (Decret 293/1984).

\section{References}

${ }^{1}$ Van Doorn R, Borm PJA, Leijdekkers CM, Henderson PT, Reuvers J, Van Bergen TJ. Detection and identification of S-methylcysteine in urine of workers exposed to methyl chloride. Int Arch Occup Environ Health 1980;46:99-109.

${ }^{2}$ Vainio H, Savolainen H, Kilpikari I. Urinary thioether of employees of a chemical plant. Br J Ind Med 1978;35:232-4.

${ }^{3}$ Yllner S. Urinary metabolities of ${ }^{14} \mathrm{C}$-tetrachloroethylene in mice. Nature 1961;191:820.

${ }^{4}$ Stewart RD, Baretta ED, Dodd HC, Torkelson TR. Experimental human exposure to tetrachloroethylene. Arch Environ Health 1970;20:224-9. 